\title{
Exogenous Spermidine Alleviates the Oxidative Damage in Cucumber Seedlings Subjected to High Temperatures
}

\author{
Jing Tian', Li-Ping Wang ${ }^{1}$, Yan-Juan Yang, Jin Sun, and Shi-Rong Guo ${ }^{2}$ \\ Key Laboratory of Southern Vegetable Crop Genetic Improvement in Ministry of Agriculture, College \\ of Horticulture, Nanjing Agricultural University, Nanjing 210095, P.R. China
}

\begin{abstract}
AdDITIONAL IndEX wORDs. Cucumis sativus, high-temperature stress, exogenous substance, oxidative stress, enzyme activity, isozyme

Abstract. Heat tolerance is considered to be an essential feature for cucumber (Cucumis sativus) production, and it has been suggested that higher antioxidant ability could prevent the oxidative damage in plants caused by hightemperature stress. We aimed to investigate whether the application of exogenous spermidine (Spd) increases antioxidant activities and, therefore, elevates the heat tolerance of cucumber. Cucumber seedlings (cv. Jinchun No. 4) showing moderate heat tolerance were grown in climate chambers to investigate the effects of exogenous Spd (1 mu) foliar spray treatment on the activities and isozyme levels of antioxidative enzymes under both high-temperature stress $42 / 32{ }^{\circ} \mathrm{C}$ (day/night) and normal temperature $28 / 18{ }^{\circ} \mathrm{C}$ (day/night). On high-temperature stress, the activities of superoxide dismutase and ascorbate peroxidase were significantly reduced; the catalase activity was initially lower and then increased, whereas the peroxidase activity was initially higher and then decreased. The levels of these isozymes also changed differently. On treatment with exogenous Spd, the activities of these antioxidant enzymes were noticeably enhanced, and the isozyme zymogram expression had some changes. It was concluded that foliar spray with Spd effectively improved the total antioxidant ability of cucumber seedlings and, therefore, enhanced the tolerance of the plants to high-temperature stress.
\end{abstract}

Temperatures above the normal optimum, usually within 10 to $15^{\circ} \mathrm{C}$, are sensed as heat shock or heat stress by all living organisms. However, heat stress is a complex process that includes factors of intensity (temperature in degrees), duration, and the rate of increase in temperature. Heat stress disturbs cellular homeostasis and can lead to severe retardation in growth and development, and even to death. As sessile organisms, plants are constantly exposed to changes in temperature and other abiotic factors. Worldwide, extensive agricultural losses are attributed to heat, often in combination with drought or other stresses (Baniwal et al., 2004). Thermal injury mechanism involves physiological and biochemical processes, including germination inhibition, photosynthesis and respiration anomalies, water deficiency, an imbalance of carbon and nitrogen metabolism, lipid peroxidation, a modulation of the levels of hormones and primary and secondary metabolites as well as protein and nucleic acid degradation (Wahid et al., 2007). In addition to tissue dehydration, heat stress may induce oxidative stress in plants, which causes lipid peroxidation and subsequent membrane injury, protein degradation, enzyme inactivation, pigment bleaching, and disruption of DNA strands (Song et al., 2006).The generation of reactive oxygen species (ROS), including singlet oxygen $\left({ }^{1} \mathrm{O}_{2}\right)$, superoxide anion $\left(\mathrm{O}_{2}^{-} \cdot\right)$, hydrogen peroxide $\left(\mathrm{H}_{2} \mathrm{O}_{2}\right)$, and hydroxyl radical (HO-), are symptoms of cellular injury resulting from high-temperature stress (Liu and Huang, 2000). Consequently, the evolution of all aerobic organisms has been dependent on the

Received for publication 9 June 2011. Accepted for publication 12 Oct. 2011. This work was supported by the National Basic Research Program of China (973 Programme; No. 2009CB119000) and an earmarked fund for Modern Agro-industry Technology Research System (CARS-25-C-03).

${ }^{1}$ These authors contributed equally to this work.

${ }^{2}$ Corresponding author. E-mail: srguo@njau.edu.cn. development of efficient ROS-scavenging mechanisms (Mittler et al., 2004). Traditionally, reactive oxygen intermediates (ROIs) were considered to be toxic byproducts of aerobic metabolism, which were disposed of by antioxidants; however, in recent years, it has become apparent that plants actively produce ROIs as signaling molecules to control processes such as programmed cell death, abiotic stress responses, pathogen defense, and systemic signaling (Mittler, 2002).

Cucumber is one of the main vegetable crops worldwide and has been cultivated in China for more than 2000 years. It is a thermophilic plant originating in subtropical regions; therefore, regarding annual production, researchers have historically placed much emphasis on damage caused by low temperature and mechanisms on chilling tolerance. However, in more recent years, heat stress has been a serious problem for crop production as a result of global warming, and high-temperature injury mechanisms and the heat tolerance of plants have attracted much attention in the research community.

Polyamines (PAs) are a class of low-molecular polycations found in all living organisms. They are aliphatic nitrogen compounds that are positively charged at a physiological $\mathrm{pH}$. In plants, they have been implicated in a variety of biological processes, including growth and development, morphogenesis, prevention of senescence, and environmental or abiotic stress responses. PAs not only act directly as a protective factor, but also as signaling molecules in the plant signal transduction conducive to building resistance to stresses (Groppa and Benavides, 2008). Plant PAs, mainly diamine putrescine (Put), triamine Spd, and tetraamine spermine (Spm), frequently accumulate in response to both abiotic and biotic stresses (Bouchereau et al., 1999). A higher level of Spd may be more related to stress resistance in cucumber than other forms of PAs (Duan et al., 2008). By participating in amino and imino through ionic 
bonds, hydrogen bonding, hydrophobic interactions, and other non-covalently with nucleic acids, protein, and charged phospholipids, PAs play an important role in stabilizing the thylakoid composition and participating in the construction of biomembranes such that they can prevent lipid from peroxidation and protein from hydrolysis, regulate the physiological activity and functions, control metabolism, and then improve plant resistance (Zhao et al., 2000). Studies using transgenic plants overexpressing the genes of PA biosynthetic enzymes support the defensive roles of PAs in response to diversified stresses. This has been verified in transformed Arabidopsis thaliana, overexpressing Spd synthase genes from fig-leaf gourd (Cucurbita $\times$ cifolia) producing strong tolerance to multiple stresses, including chilling, freezing, salinity, drought, and paraquat toxicity (Kasukabe et al., 2004). Previous studies in our laboratory found that $50 \mathrm{~mm} \mathrm{NaCl}$ stress caused a clear suppression of growth in salinity-sensitive cucumber seedlings, and $0.1 \mathrm{~mm}$ Spd application to salinized nutrient solution (Duan et al., 2008) or $1 \mathrm{~mm}$ Spd spraying on leaves (Du et al., 2010) can effectively reverse the inhibition. However, few studies explored the role of PAs in temperature stress. Shen et al. (2000) sprayed cucumber leaves with $1 \mathrm{~mm}$ PAs (Put, Spd, or Spm) and found that Spd plays a central role in the chilling tolerance of cucumber through preventing chill-induced activation of NADPH oxidases in microsomes. S-adenosyl-1-methionine decarboxylase (SAMDC) is one of the key regulatory enzymes in PA biosynthesis; transgenic tomato overexpressing yeast $S A M D C$ induced higher levels of Spd and Spm to enhance antioxidant enzyme activity and the tolerance to high-temperature stress (Cheng et al., 2009). In the present study, we aim to examine the impact of high-temperature stress on the activities and isozyme expression of antioxidant enzymes in cucumber seedlings and to assess the possible protective or reversible effect of exogenous Spd application from the oxidative damage caused by hightemperature stress.

\section{Materials and Methods}

Plant material and stress treatments. Cucumber (cv. Jinchun No. 4) seeds were germinated on moist gauze in the dark at $29^{\circ} \mathrm{C}$ for $30 \mathrm{~h}$. The germinated seedlings were transferred to plastic pots (10-cm diameter, one seedling per pot) containing quartz sand and grown in a greenhouse at Nanjing Agricultural University at 25 to $29^{\circ} \mathrm{C}$ (day) and 15 to $19^{\circ} \mathrm{C}$ (night) under natural light. The relative humidity $(\mathrm{RH})$ ranged between $60 \%$ and $75 \%$. Instead of fresh water irrigation, when the cotyledons expanded, the seedlings were supplied with water containing half-strength Hoagland's nutrient solution $[\mathrm{pH}$ $6.5 \pm 0.1$, electrical conductivity (EC) 2.0 to $2.2 \mathrm{dS} \cdot \mathrm{m}^{-1}$ ]. After full development of the third leaf of each plant, they were transferred into two artificial growth chambers under the following conditions: a 12 -h photoperiod, $28 / 18{ }^{\circ} \mathrm{C}$ (day/night), a light intensity of $350 \mu \mathrm{mol} \cdot \mathrm{m}^{-2} \cdot \mathrm{s}^{-1}$, and RH $70 \%$ to $75 \%$. After $2 \mathrm{~d}$ of pre-culture, the seedlings in one chamber as the hightemperature stress group were exposed to $42 / 32{ }^{\circ} \mathrm{C}$ (day/night). The four experimental treatments were as follows: 1) T1, control plants were grown under $28 / 18{ }^{\circ} \mathrm{C}$ (day/night) and the leaves were sprayed with deionized water; 2) T1+, plants were grown under $28 / 18{ }^{\circ} \mathrm{C}$ (day/night) and the leaves were sprayed with $1 \mathrm{mmol} \cdot \mathrm{L}^{-1} \mathrm{Spd}$; 3 ) T2, plants were grown under $42 / 32^{\circ} \mathrm{C}$ (day/night) and the leaves were sprayed with deionized water; and 4) $\mathrm{T} 2+$, plants were grown under $42 / 32{ }^{\circ} \mathrm{C}$ (day/night) and the leaves were sprayed with $1 \mathrm{~mm}$ Spd (Sigma-Aldrich Chemical Co., St. Louis, MO). Tween-20 (0.5\%, v/v; Haijiechem, Zibo, China) was used as a surfactant. Approximately $25 \mathrm{~mL}$ of solution sprayed for 16 plants in one tray was carried out at $1700 \mathrm{HR}$ everyday. The fully expanded third leaves of the heat-stressed and control plants were sampled after 1, 3, and $5 \mathrm{~d}$ (between 0800 and $0900 \mathrm{HR}$ ), immediately snap-frozen in liquid nitrogen, and stored at $-80{ }^{\circ} \mathrm{C}$ until required for analysis.

Determination OF GROWTH. Plant height was measured by a ruler with an accuracy of $1 \mathrm{~mm}$ from cotyledons to the apical point. Stem diameter was measured by a vernier caliper with an accuracy of $0.05 \mathrm{~mm}$ at a consistent point $1 \mathrm{~cm}$ below cotyledons. The area of the third and fourth leaves on a plant was measured using a scanner (Expression 1680; Epson America, Long Beach, CA). Before determination of fresh weight, the seedlings were washed using deionized water. After measuring the fresh weight, samples were dried in an oven at $105^{\circ} \mathrm{C}$ for $15 \mathrm{~min}$ followed by $75^{\circ} \mathrm{C}$ for $72 \mathrm{~h}$, until they reached a constant weight, and then weighed for dry weight. Relative growth rate (RGR) was measured according to Hunt (1990).

Polyamine analysis. Polyamines were extracted according to Sharma and Rajam (1995) with some modifications. Fresh leaf samples were homogenized in $3.2 \mathrm{~mL}$ of $5 \%(\mathrm{v} / \mathrm{v})$ cold perchloric acid and incubated at $4{ }^{\circ} \mathrm{C}$ for $1 \mathrm{~h} .1,6$-Hexanediamine was added to the homogenate as the internal standard. Then the homogenate was centrifuged at $12,000 g_{n}$ for $30 \mathrm{~min}$ at $4{ }^{\circ} \mathrm{C}$. The supernatant was used to determine free and soluble conjugated polyamines, and the pellet was used to determine insoluble bound polyamines, as described by Duan et al. (2008).

DETERMINATION OF MEMBRANE DAMAGE AND FREE RADICAL PRODUCTION. Malondialdehyde (MDA) content was determined by the thiobarbituric acid reaction following the method of Heath and Packer (1968). The lipoxygenase (LOX) activity was measured following the method of Axelrod et al. (1981) with modifications. $\mathrm{O}_{2}{ }^{-}$. production rate was measured according to Elstner and Heupel (1976). $\mathrm{H}_{2} \mathrm{O}_{2}$ content was measured by the titanium method according to Patterson et al. (1984).

Assay of antioxidant ENZYMe activity. The leave sample $(0.2 \mathrm{~g})$ was homogenized with a mortar and pestle in $1.6 \mathrm{~mL}$ ice-cold phosphate buffer $(50 \mathrm{~mm}, \mathrm{pH} 7.8)$ containing $1 \%(\mathrm{w} / \mathrm{v})$ insoluble polyvinylpolypyrrolidone (PVPP). The extract was kept on ice for $10 \mathrm{~min}$ and then centrifuged at $12,000 g_{\mathrm{n}}$ for 20 $\min$ at $4{ }^{\circ} \mathrm{C}$. The supernatant was used to measure enzyme activity. Superoxide dismutase (SOD) (EC 1.15.1.1) activity was measured according to Giannopolitis and Ries (1977) with minor modification. One unit of activity was defined as the amount of enzyme required to cause a $50 \%$ inhibition of the photochemical reduction of nitroblue tetrazolium (NBT), which was monitored at $560 \mathrm{~nm}$ using a spectrophotometer (WFZ ultraviolet/VIS-2600; UNIC, Shanghai, China). Peroxidase (POD) (EC 1.11.1.7) activity was measured according to Kochba et al. (1977), and one unit of activity was defined as the amount of enzyme required to increase the optical density at $470 \mathrm{~nm} \cdot \mathrm{min}^{-1}$ by 1 absorbance unit. Catalase (CAT) (EC 1.11.1.6) activity was measured according to Aebi (1984), and one unit of activity was defined as the amount of enzyme required to decrease the optical density at $240 \mathrm{~nm} \cdot \mathrm{min}^{-1}$ by 0.1 absorbance units. Ascorbate peroxidase (APX) (EC 1.11.1.11) activity was measured according to Nakano and Asada (1987), and one unit of activity was defined as the amount of APX catalyzing the oxidation of $1 \mu \mathrm{mol}$ ascorbate at $290 \mathrm{~nm} \cdot \mathrm{min}^{-1}$. The protein concentration of the enzyme extract was determined according 
to the Bradford (1976) method using bovine serum albumin as a standard.

NATIVE GEL ELECTROPHORESIS FOR ISOZYME VISUALIZATION. Frozen samples $(0.2 \mathrm{~g})$ were finely ground to powder in liquid nitrogen and homogenized in $0.8 \mathrm{~mL}$ phosphate buffer $(0.1 \mathrm{M}$, $\mathrm{pH} 7.0$ ) containing $15 \%$ sucrose, $0.2 \% \beta$-mercaptoethanol, and $1 \%$ PVPP. The homogenate was centrifuged at $12,000 g_{n}$ for 20 min at $4{ }^{\circ} \mathrm{C}$, and the supernatant was centrifuged again. For the extraction of APX, $10 \mathrm{~mm}$ AsA and $1 \mathrm{~mm}$ EDTA were added. Native polyacrylamide gel electrophoresis (PAGE), using 3\% concentrated gel and $8 \%$ separating gel, was performed at 100 $\mathrm{V}$ for 60 to $70 \mathrm{~min}$ at $4{ }^{\circ} \mathrm{C}$ (in a refrigerator) and then at $200 \mathrm{~V}$ for $\approx 3.5$ to $4 \mathrm{~h}$.

SOD isozymes were detected according to Beauchamp and Fridovich (1971). The gel was equilibrated with $36 \mathrm{~mm}$ potassium phosphate buffer ( $\mathrm{pH} 7.8$ ) containing $28 \mu \mathrm{M}$ riboflavin and $28 \mathrm{~mm} \mathrm{~N}, \mathrm{~N}, \mathrm{~N}^{\prime}, \mathrm{N}^{\prime}$-tetramethylethylenediamine (TEMED) for $30 \mathrm{~min}$ and then washed in deionized water for $1 \mathrm{~min}$ and submerged with gentle agitation in same buffer adding $2.45 \mathrm{~mm}$ NBT for 10 to $20 \mathrm{~min}$. In the presence of light, the SOD enzymes appeared as colorless bands on a blue or purple background. POD isozymes were detected with a staining solution containing $0.2 \%(\mathrm{w} / \mathrm{v})$ benzidine (a small amount of acetic acid was used to dissolve the compound), $0.4 \%(\mathrm{w} / \mathrm{v})$ ammonium chloride, $0.5 \%(\mathrm{w} / \mathrm{v})$ disodium ethylenediamine tetraacetate, and $0.03 \%(\mathrm{w} / \mathrm{v}) \mathrm{H}_{2} \mathrm{O}_{2}$. Gel was soaked in the mixture with gentle shaking and the color develops very quickly, which appeared within 3 to $5 \mathrm{~min}$. Then gel was rinsed with deionized water to stop coloring. CAT isozymes were visualized using the method of Woodbury et al. (1971) with slight modifications. After electrophoretic separation, the gel was incubated in $0.005 \%$ $\mathrm{H}_{2} \mathrm{O}_{2}$ for $15 \mathrm{~min}$, washed with deionized water, and then incubated in $1 \%$ ferric chloride $\left(\mathrm{FeCl}_{3}\right)$ and $1 \%$ potassium ferricyanide $\left\{\mathrm{K}_{3}\left[\mathrm{Fe}(\mathrm{CN})_{6}\right]\right\}$ for 5 to $10 \mathrm{~min}$. According to Mittler and Zilinskas (1993), APX isozymes were stained after equilibration of the gel first in potassium phosphate buffer $(0.1 \mathrm{M}$, $\mathrm{pH} 7.0$ ) containing $2 \mathrm{~mm}$ ascorbate for $30 \mathrm{~min}$ and then in the buffer containing $4 \mathrm{~mm}$ ascorbate and $2 \mathrm{mM} \mathrm{H}_{2} \mathrm{O}_{2}$ for $20 \mathrm{~min}$. Then the gel was submerged in potassium phosphate buffer $(50$ $\mathrm{mm}, \mathrm{pH} 7.8$ ) containing $28 \mathrm{~mm}$ TEMED and $2.45 \mathrm{~mm}$ NBT with gentle agitation. The reaction was continued for $10 \mathrm{~min}$ and stopped by a brief wash in deionized water. The stained gels were scanned using the Image Scanner III software (GE Healthcare, Piscataway, NJ).
STATISTICAL ANALYSIS. All of the experiments were performed in triplicate, and the results were presented as the means \pm SE. All data were statistically analyzed with SAS (Version 8.2; SAS Institute, Cary, NC) using Duncan's multiple range test at a level of significance of 0.05 .

\section{Results}

Growth. In the present study, the plant height, stem diameter, leaf area, shoot fresh weight, and RGR were significantly decreased $5 \mathrm{~d}$ after starting high-temperature treatment $(P<0.05)$ compared with the control. The area of the fourth leaf (new leaf blade) was more seriously restricted by the high-temperature stress than that of the third leaf. Application of exogenous $1 \mathrm{~mm}$ Spd (sprayed on leaves) greatly alleviated the heat-mediated growth reduction in the cucumber plants (Table 1).

Polyamine content. The polyamine content after $5 \mathrm{~d}$ of treatment is shown in Table 2, including Put, Spd, and Spm in the free, soluble conjugated, and insoluble bound forms. Five $\mathrm{d}$ after exposure to high temperature, the free Put content of cucumber seedlings decreased in leaves, whereas the content of Spd and Spm in leaves increased. The downward trend on free Put level in leaves was modified by the exogenous Spd application. Under high-temperature stress, exogenous Spd induced further accumulation of free Spd in leaves, whereas the free Spm content was a little lower than that without Spd spraying. The two other forms of polyamine, soluble conjugated and insoluble bound, showed a similar trend with the free form. High temperature resulted in a decreased level of Put in soluble conjugated and insoluble bound form and increased Spd and Spm levels of the two forms. Compared with high-temperature stress alone, the application of exogenous Spd promoted the two forms of Put and Spd to accumulate and inhibited the Spm content of the two forms.

Membrane damage. High-temperature stress caused a significant increase in the MDA content in leaves of cucumber seedlings. Exogenous Spd application markedly inhibited this increase such that there were no significant difference between the treatment of $\mathrm{T} 2+$ and the control (Fig. 1A). The LOX activity in leaves was numerically higher under the high-temperature stress than the control, but the difference was not significant at the $P<0.05$ level. Exogenous Spd reduced the LOX activity, regardless of the temperature. In particular, treatment with $\mathrm{Spd}$

Table 1. Effect of exogenous application of $1 \mathrm{~mm}$ spermidine (Spd) on the growth parameters of cucumber seedlings exposed to normal or high temperature stress for $5 \mathrm{~d}$.

\begin{tabular}{|c|c|c|c|c|}
\hline \multirow[b]{2}{*}{ Treatments } & $\mathrm{T} 1^{\mathrm{z}}$ & $\mathrm{T} 1+^{\mathrm{z}}$ & $\mathrm{T} 2^{\mathrm{z}}$ & $\mathrm{T} 2+^{\mathrm{z}}$ \\
\hline & \multicolumn{4}{|c|}{$(\text { mean } \pm \mathrm{SE})^{\mathrm{y}}$} \\
\hline Plant ht (cm/plant) & $15.46 \pm 0.32 \mathrm{~b}^{\mathrm{x}}$ & $17.23 \pm 0.63 \mathrm{a}$ & $12.13 \pm 0.33 \mathrm{c}$ & $14.50 \pm 0.34 \mathrm{~b}$ \\
\hline Stem diam (mm/plant) & $7.13 \pm 0.13 b$ & $7.58 \pm 0.13 \mathrm{a}$ & $6.23 \pm 0.16 \mathrm{c}$ & $6.88 \pm 0.15 b$ \\
\hline Shoot dry wt (g/plant) & $0.92 \pm 0.05 \mathrm{ab}$ & $1.00 \pm 0.04 \mathrm{a}$ & $0.81 \pm 0.03 \mathrm{~b}$ & $0.94 \pm 0.03 \mathrm{a}$ \\
\hline Third leaf area $\left(\mathrm{cm}^{2} /\right.$ plant $)$ & $84.18 \pm 2.97 \mathrm{a}$ & $89.38 \pm 2.42 \mathrm{a}$ & $68.90 \pm 3.52 b$ & $81.34 \pm 3.30 \mathrm{a}$ \\
\hline Fourth leaf area $\left(\mathrm{cm}^{2} /\right.$ plant $)$ & $78.15 \pm 3.31 \mathrm{~b}$ & $93.44 \pm 2.61 \mathrm{a}$ & $59.94 \pm 3.55 \mathrm{c}$ & $86.30 \pm 3.61 \mathrm{ab}$ \\
\hline
\end{tabular}

${ }_{\mathrm{z}} \mathrm{T} 1=$ control plants under $28 / 18^{\circ} \mathrm{C}\left(\right.$ day/night); T1 $+=$ plants under $28 / 18^{\circ} \mathrm{C}$ with Spd foliar spraying; T2 = plants under $42 / 32{ }^{\circ} \mathrm{C} ; \mathrm{T} 2+=$ plants under $42 / 32^{\circ} \mathrm{C}$ with $\mathrm{Spd}$ foliar spraying.

${ }^{y}$ Means of 12 replicates in three separate experiments.

xDifferent letters indicate significant differences between treatments by Duncan's multiple range test at $P<0.05$.

$\mathrm{RGR}=$ relative growth rate. 
Table 2. Effect of exogenous application of $1 \mathrm{~mm}$ spermidine (Spd) on the polyamine content in leaves of cucumber seedlings exposed to normal or high temperature stress for $5 \mathrm{~d}$.

\begin{tabular}{|c|c|c|c|c|c|}
\hline \multirow[b]{2}{*}{$\underline{\text { Polyamine content }}^{z}$} & & $\mathrm{~T} 1^{\mathrm{y}}$ & $\mathrm{T} 1+\mathrm{y}$ & $\mathrm{T} 2^{\mathrm{y}}$ & $\mathrm{T} 2+\mathrm{y}$ \\
\hline & & \multicolumn{4}{|c|}{ Mean \pm SE $\left(\mathrm{nmol} \cdot \mathrm{g}^{-1} \text { fresh weight }\right)^{\mathrm{x}}$} \\
\hline \multirow[t]{3}{*}{ Free polyamine content } & Put & $92.34 \pm 4.04 b^{w}$ & $111.10 \pm 5.19 \mathrm{a}$ & $61.96 \pm 4.48 \mathrm{c}$ & $78.84 \pm 6.90 \mathrm{bc}$ \\
\hline & Spd & $215.41 \pm 10.40 \mathrm{c}$ & $239.26 \pm 13.18 \mathrm{c}$ & $276.63 \pm 4.70 b$ & $312.54 \pm 8.71 \mathrm{a}$ \\
\hline & Spm & $23.87 \pm 1.24 \mathrm{c}$ & $19.37 \pm 1.81 \mathrm{c}$ & $37.09 \pm 1.19 \mathrm{a}$ & $29.43 \pm 1.85 \mathrm{~b}$ \\
\hline \multirow[t]{3}{*}{ Soluble conjugated polyamine content } & Put & $46.86 \pm 1.00 \mathrm{a}$ & $44.78 \pm 1.884 \mathrm{a}$ & $26.77 \pm 2.04 \mathrm{c}$ & $33.26 \pm 1.29 \mathrm{~b}$ \\
\hline & Spd & $54.64 \pm 3.91 \mathrm{c}$ & $62.65 \pm 1.78 \mathrm{c}$ & $77.00 \pm 4.21 \mathrm{~b}$ & $93.77 \pm 3.76 \mathrm{a}$ \\
\hline & Spm & $5.68 \pm 0.90 b$ & $6.61 \pm 0.49 b$ & $14.96 \pm 0.60 \mathrm{a}$ & $12.78 \pm 0.75 \mathrm{a}$ \\
\hline \multirow[t]{3}{*}{ Insoluble bound polyamine content } & Put & $8.76 \pm 0.23 \mathrm{a}$ & $9.21 \pm 0.29 \mathrm{a}$ & $2.80 \pm 0.25 \mathrm{c}$ & $4.33 \pm 0.44 b$ \\
\hline & Spd & $26.91 \pm 3.96 \mathrm{c}$ & $29.98 \pm 1.66 \mathrm{c}$ & $64.01 \pm 2.77 b$ & $79.32 \pm 2.86 \mathrm{a}$ \\
\hline & Spm & $3.99 \pm 0.29 b$ & $3.60 \pm 0.52 b$ & $7.50 \pm 0.54 \mathrm{a}$ & $6.54 \pm 0.25 \mathrm{a}$ \\
\hline
\end{tabular}

${ }^{\mathrm{z}} \mathrm{Put}=$ putrescine; $\mathrm{Spd}=$ spermidine; Spm $=$ spermine.

${ }^{\mathrm{y}} \mathrm{T} 1=$ control plants under $28 / 18{ }^{\circ} \mathrm{C}\left(\right.$ day/night); $\mathrm{T} 1+=$ plants under $28 / 18{ }^{\circ} \mathrm{C}$ with Spd foliar spraying; $\mathrm{T} 2=$ plants under $42 / 32{ }^{\circ} \mathrm{C}$; $\mathrm{T} 2+=$ plants under $42 / 32{ }^{\circ} \mathrm{C}$ with Spd foliar spraying.

${ }^{\mathrm{x}}$ Means of three replicates in three separate experiments.

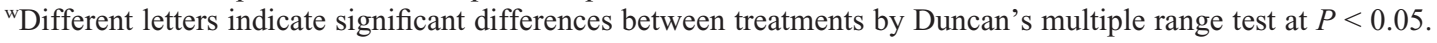

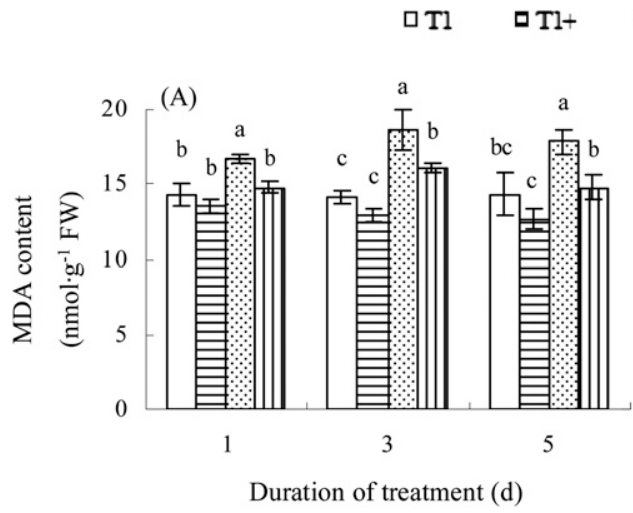

$\mathrm{ET} 2 \mathrm{~T} \mathrm{~T} 2+$

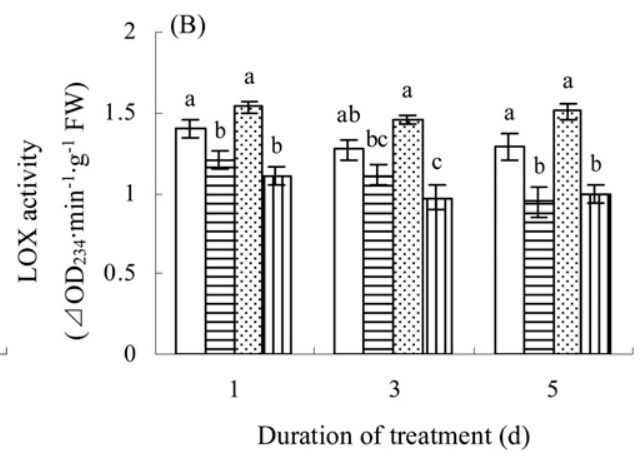

Fig. 1. Effect of high-temperature stress and/or exogenous application of $1 \mathrm{~mm}$ spermidine (Spd) on the malondialdehyde (MDA) content (A) and lipoxygenase (LOX) activity (B) in leaves of cucumber seedlings during treatments for 1,3 , and $5 \mathrm{~d}$; $\mathrm{T} 1=$ control plants under $28 / 18^{\circ} \mathrm{C}$ (day/night). $\mathrm{T} 1+=$ plants under $28 / 18^{\circ} \mathrm{C}$ with Spd foliar spraying; T2 = plants under $42 / 32{ }^{\circ} \mathrm{C}$; and T2 $+=$ plants under $42 / 32{ }^{\circ} \mathrm{C}$ with Spd foliar spraying. Each histogram represents a mean value of three independent experiments and the vertical bars indicate SE $(n=3)$. Different letters indicate significant differences between treatments by Duncan's multiple range test at $P<0.05$.

inhibited the increase of the LOX activity under high-temperature stress (Fig. 1B).

Free radical production. As shown in Figure 2A, under high-temperature stress, the $\mathrm{O}_{2}^{-}$. production rate in leaves was significantly increased (by $38.7 \%$ up to $5 \mathrm{~d}$ of treatment) compared with the control. Application of exogenous Spd significantly reduced the high temperature-induced free radical production to a level close to the control. A similar trend was observed for the $\mathrm{H}_{2} \mathrm{O}_{2}$ content (Fig. 2B), which increased to $131 \%$ of the control under high-temperature stress, whereas it decreased to $113 \%$ in the presence of Spd after $5 \mathrm{~d}$ of treatment.

Antioxidant enzyme activities. Among the four antioxidant enzymes tested, SOD was the most susceptible to hightemperature stress (Fig. 3). Only $1 \mathrm{~d}$ the temperature increased from $28 / 18{ }^{\circ} \mathrm{C}$ to $42 / 32{ }^{\circ} \mathrm{C}$ (day/night); the SOD activity in leaves was significantly lower than the control. Under hightemperature stress for 1,3 , and $5 \mathrm{~d}$, SOD activity was just $68.5 \%, 80.2 \%$, and $52.9 \%$ of control plant, respectively (Fig.
3A). Similarly, APX activity declined during the high-temperature treatment, $\approx 20 \%$ lower than the control (Fig. 3D). Although CAT activity was also significantly inhibited $18.6 \%$ by high-temperature stress initially, with the time of treatment, it was recovered gradually. Exposed to high temperature for $5 \mathrm{~d}$, CAT activity was even $14.9 \%$ higher than the control (Fig. 3C). Heat stress created different effects on POD activity. High temperature greatly induced POD activity in leaves after treatment for $1 \mathrm{~d}, 25.4 \%$ higher than the control, whereas it then declined gradually to the control level (Fig. 3B). Whether the plants were exposed to high temperature or normal temperature, foliar application of exogenous Spd consistently elevated these activities of antioxidant enzymes. However, it was more important to promote antioxidant ability under stress condition. Five $\mathrm{d}$ after starting high-temperature treatment, the activities of SOD, POD, and APX were enhanced $48.5 \%, 15.6 \%$, and $18.2 \%$ by exogenous Spd, respectively.

Superoxide dismutase, peroxidase, Catalase, and ASCORBATE PEROXIDASE ISOENZYMES. The expression of isozymes of SOD, POD, CAT, and APX in leaves of cucumber seedlings were analyzed as shown in Figures 4 through 7 . We observed four SOD isozymes on native PAGE gels of cucumber seedlings in leaves. These bands were identified as S1, S2, S3, and $\mathrm{S} 4$ and had relative mobility $\left(\mathrm{R}_{\mathrm{f}}\right)$ values of $0.276,0.492,0.561$, and 0.602 , respectively (Fig. 4). The S3 band was the most abundant and the $\mathrm{S} 2$ band was the least abundant. S2 was very sensitive to high temperature and nearly disappeared after $1 \mathrm{~d}$ of treatment. S4 was also inhibited by high-temperature stress. Under hightemperature stress, the expressions of all four SOD isozymes were enhanced at $3 \mathrm{~d}$ than at $1 \mathrm{~d}$, but then they were weakened with the time of treatment. With high-temperature treatment for $5 \mathrm{~d}$, the 

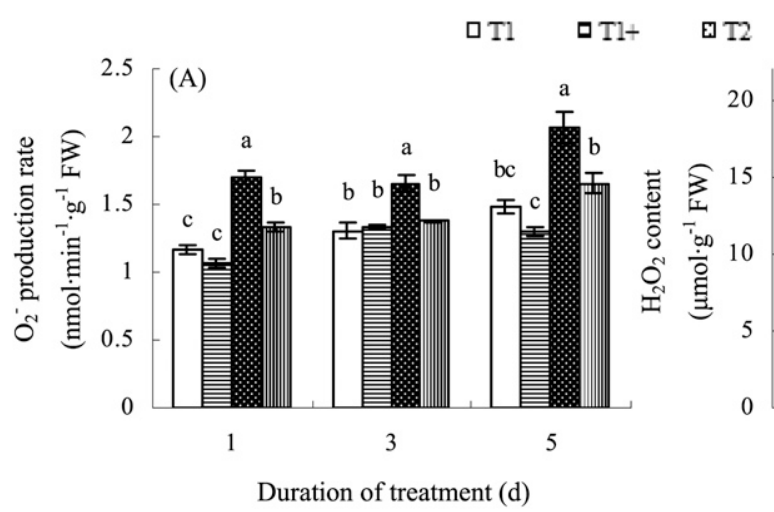

Fig. 2. Effect of high-temperature stress and/or exogenous application of 1 mu spermidine (Spd) on the superoxide anion $\left(\mathrm{O}_{2}^{-} \cdot\right.$ ) production rate $(\mathbf{A})$ and hydrogen peroxide $\left(\mathrm{H}_{2} \mathrm{O}_{2}\right)$ content $(\mathbf{B})$ in leaves of cucumber seedlings during treatments for 1,3 , and $5 \mathrm{~d}$; $\mathrm{T} 1=$ control plants under $28 / 18^{\circ} \mathrm{C}$ (day/night). $\mathrm{T} 1+=$ plants under $28 / 18^{\circ} \mathrm{C}$ with Spd foliar spraying; T2 = plants under $42 / 32{ }^{\circ} \mathrm{C}$; and T2 $+=$ plants under $42 / 32{ }^{\circ} \mathrm{C}$ with Spd foliar spraying. Each histogram represents a mean value of three independent experiments and the vertical bars indicate SE (n= 3). Different letters indicate significant differences between treatments by Duncan's multiple range test at $P<$ 0.05 .

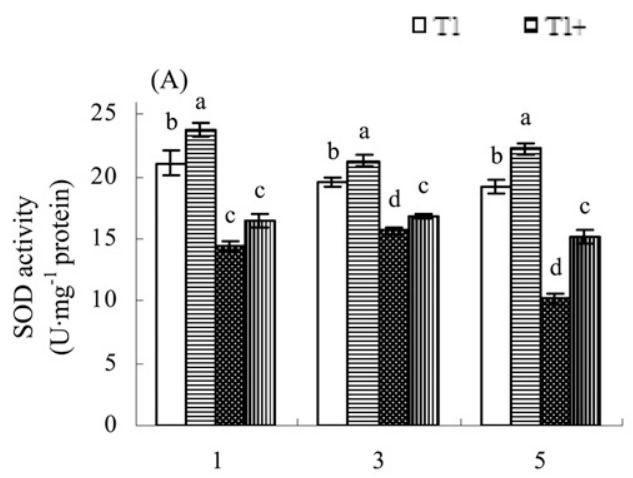

$$
\text { ET } 2 \text { प } T 2+
$$
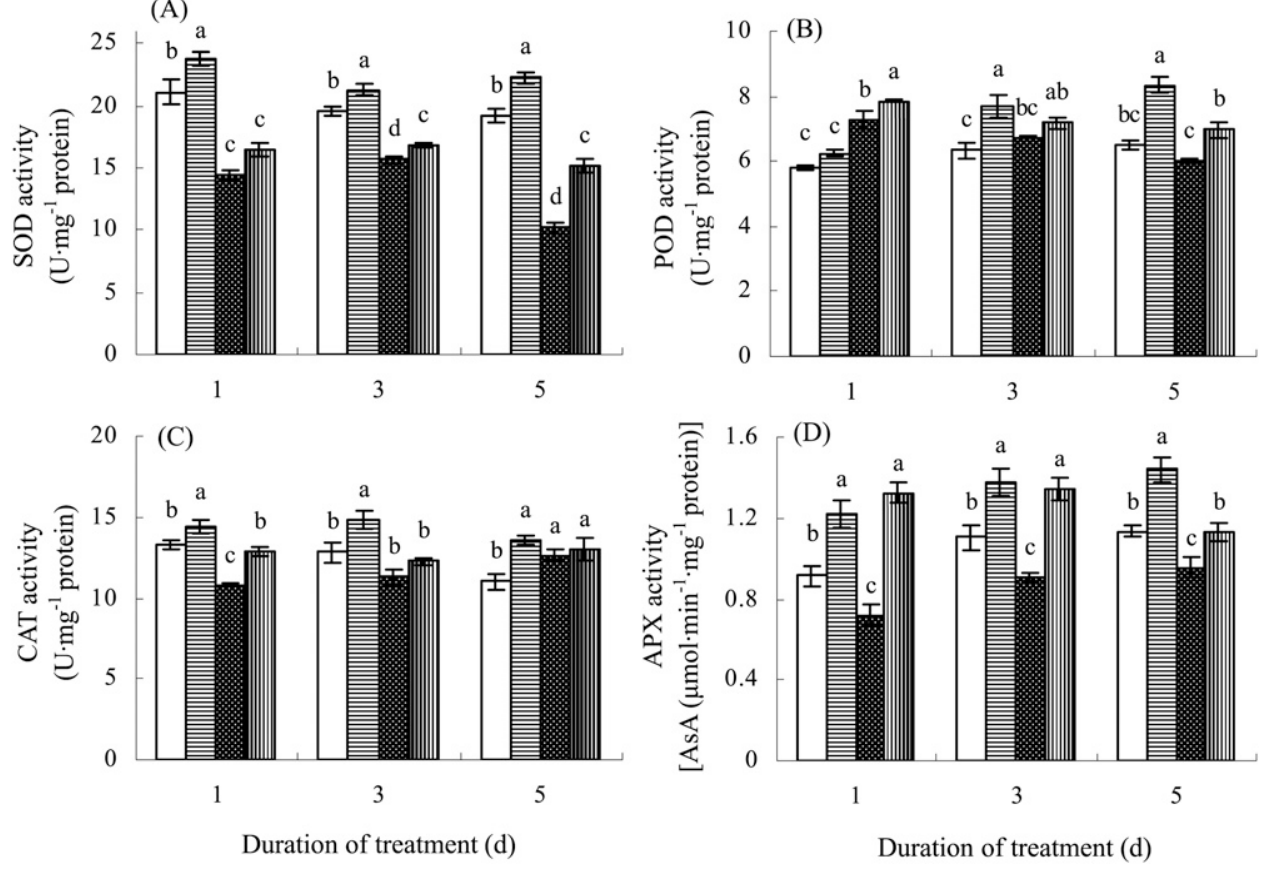

Fig. 3. Effect of high-temperature stress and/or exogenous application of $1 \mathrm{~mm}$ spermidine (Spd) on the activity of antioxidant enzymes superoxide dismutase (SOD) (A), peroxidase (POD) (B), catalase (CAT) (C), and ascorbate peroxidase (APX) (D) in leaves of cucumber seedlings during treatments for 1, 3, and $5 \mathrm{~d}$. T1 = control plants under $28 / 18^{\circ} \mathrm{C}$ (day/night); $\mathrm{T} 1+=$ plants under $28 / 18^{\circ} \mathrm{C}$ with Spd foliar spraying; $\mathrm{T} 2=$ plants under $42 / 32^{\circ} \mathrm{C}$; and $\mathrm{T} 2+=$ plants under $42 / 32{ }^{\circ} \mathrm{C}$ with Spd foliar spraying. Each histogram represents a mean value of three independent experiments and the vertical bars indicate SE $(n=3)$. Different letters indicate significant differences between treatments by Duncan's multiple range test at $P<0.05$.

bands of S2, S3, and S4 were visually weaker than in the control, whereas exogenous Spd application increased their expression markedly, especially the predominant band $\mathrm{S} 3$. This observation was consistent with the trend of SOD activity.

Five isozymes for POD were identified (Fig. 5): four with compact bands (P2, P3, P4, and P5) of moderate mobility and one with a band (P1) of low mobility. They had $\mathrm{R}_{\mathrm{f}}$ values of $0.051,0.357,0.393,0.429$, and 0.469 , respectively. The $\mathrm{P} 2$ and
P3 bands were the most abundant. When the temperature increased from normal to high, the P4 and P5 bands increased their intensity, whereas the other isozymes decreased their intensity. The expressions of these POD isozymes were not visibly influenced by exogenous Spd application. Thus, the POD isozyme profiles were not completely consistent with the changes of POD activity (Fig. 3B).

Only two bands, $\mathrm{C} 1$ and $\mathrm{C} 2$, with $\mathrm{R}_{\mathrm{f}}$ values of 0.061 and 0.143 were detected for CAT isozymes (Fig. 6). $\mathrm{C} 2$ was the main band that was readily observable throughout the treatments. Under normal temperature, exogenous Spd resulted in significant enhancement of the expression of the $\mathrm{C} 2$, which was consistent with its impact on CAT activity. Hightemperature treatment for $1 \mathrm{~d}$ reduced the expression of $\mathrm{C} 2$, and this reduction was alleviated by exogenous Spd application. Interestingly, the $\mathrm{C} 1$ band appeared and the expression of the $\mathrm{C} 2$ band increased after $3 \mathrm{~d}$ of high-temperature treatment. Exogenous Spd further increased the expression of these two CAT isozymes under high-temperature stress.

APX was present as six isozymes in leaves of cucumber seedlings. These bands were identified as P1 to P6 with $R_{\mathrm{f}}$ values of $0.056,0.184$, $0.327,0.403,0.536$, and 0.612 , respectively (Fig. 7). The A6 band was the most abundant. Both A1 and A2 bands were diffuse, whereas A3 and A4 bands were very faint. After $1 \mathrm{~d}$ starting high-temperature treatment, A5 and A6 bands decreased. Exogenous Spd application enhanced the expression of A1 and A2, although this enhancement was not restricted by temperature. After $3 \mathrm{~d}$ of treatment, we did find that high temperature and/or Spd had a certain upregulation effect on the expression of APX isozymes. There was a certain complementarity between the different bands; if the expression of A1 and A2 were relatively stronger, then the expression of A5 and A6 became weaker. Overall, Spd further enhanced the expression of the predominant A6 band.

\section{Discussion and Conclusions}

High-temperature stress causes adverse effects on plant growth and productivity. Growth analysis is widely used as a tool for 


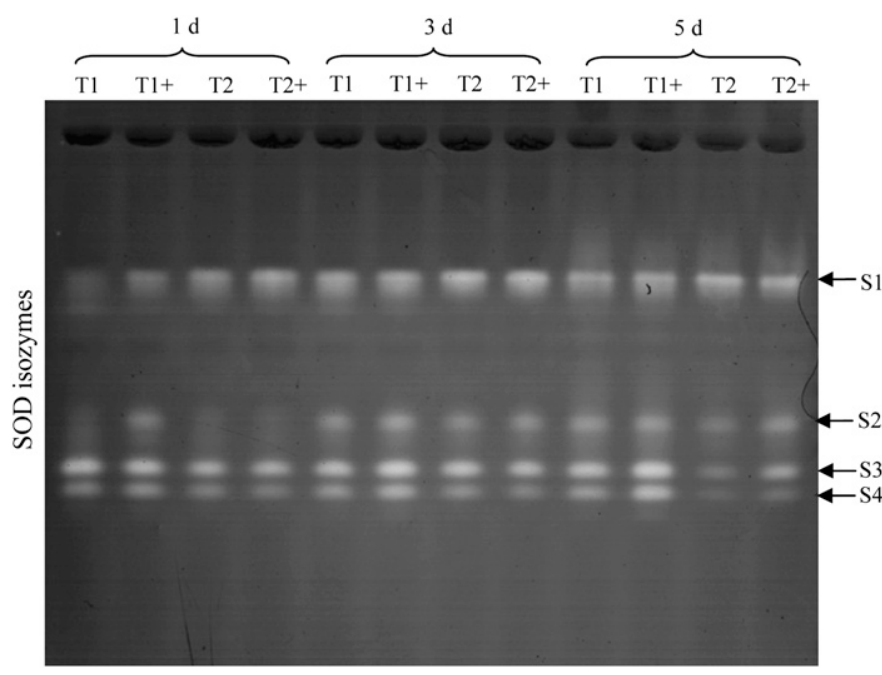

Fig. 4. Effect of high-temperature stress and/or exogenous application of $1 \mathrm{~mm}$ spermidine (Spd) on the superoxide dismutase (SOD) isozymes in leaves of cucumber seedlings during treatments for 1,3 , and $5 \mathrm{~d}$. SOD isozymes were detected on $8 \%$ native polyacrylamide gels; $\mathrm{T} 1=$ control plants under $28 / 18^{\circ} \mathrm{C}$ (day/night). $\mathrm{T} 1+=$ plants under $28 / 18^{\circ} \mathrm{C}$ with Spd foliar spraying; $\mathrm{T} 2=$ plants under $42 / 32{ }^{\circ} \mathrm{C}$; and $\mathrm{T} 2+=$ plants under $42 / 32{ }^{\circ} \mathrm{C}$ with Spd foliar spraying. Arrows indicate the SOD isozymes detected by staining.

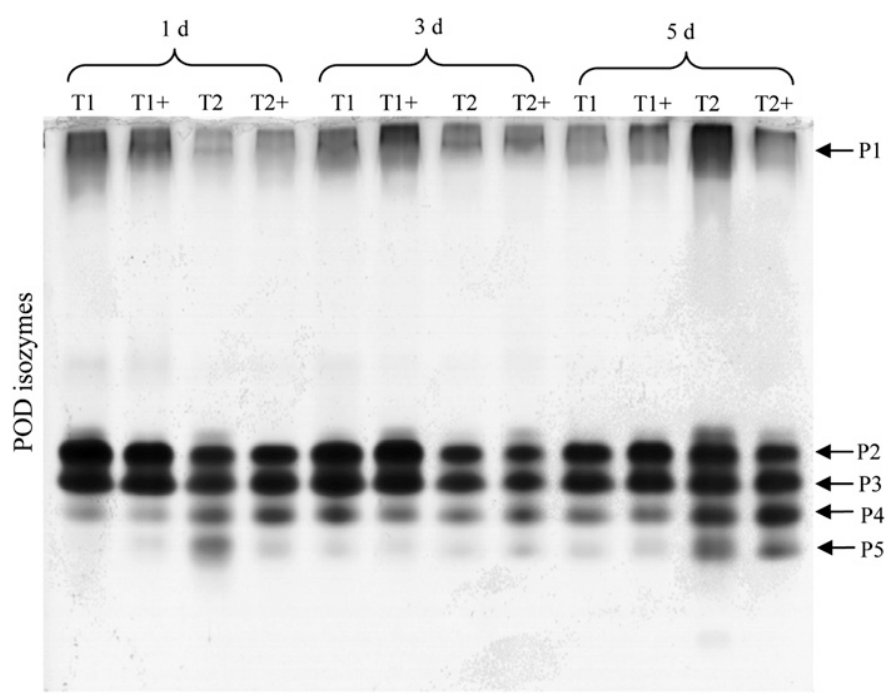

Fig. 5. Effect of high-temperature stress and/or exogenous application of $1 \mathrm{~mm}$ spermidine (Spd) on the peroxidase (POD) isozymes in leaves of cucumber seedlings during treatments for 1,3 , and $5 \mathrm{~d}$. POD isozymes were detected on $8 \%$ native polyacrylamide gels. $\mathrm{T} 1=$ control plants under $28 / 18{ }^{\circ} \mathrm{C}$ (day/ night); $\mathrm{T} 1+=$ plants under $28 / 18{ }^{\circ} \mathrm{C}$ with Spd foliar spraying; $\mathrm{T} 2=$ plants under $42 / 32{ }^{\circ} \mathrm{C}$; and $\mathrm{T} 2+=$ plants under $42 / 32{ }^{\circ} \mathrm{C}$ with Spd foliar spraying. Arrows indicate the POD isozymes detected by staining.

characterizing plant growth. Our results showed that $1 \mathrm{~mm}$ exogenous Spd sprayed on cucumber leaves significantly alleviated the growth inhibition by heat stress and increased biomass accumulation. Higher plant height and greater leaf area are conducive to maintaining the advantages of photosynthesis. It is probable that Spd was involved in the regulation of plant development under heat stress.

In general, plant species and cultivars with strong tolerance to stresses are endowed with a great capacity to enhance polyamine biosynthesis in response to environmental stresses. Among

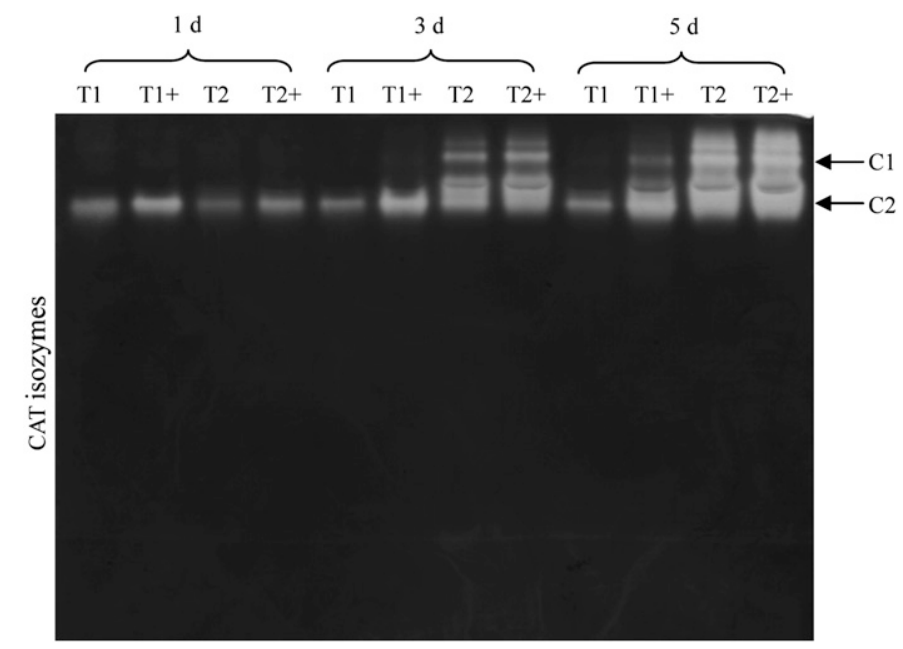

Fig. 6. Effect of high-temperature stress and/or exogenous application of $1 \mathrm{~mm}$ spermidine (Spd) on the catalase (CAT) isozymes in leaves of cucumber seedlings during treatments for 1,3 , and $5 \mathrm{~d}$. CAT isozymes were detected on $8 \%$ native polyacrylamide gels. $\mathrm{T} 1=$ control plants under $28 / 18{ }^{\circ} \mathrm{C}$ (day/ night); $\mathrm{T} 1+=$ plants under $28 / 18{ }^{\circ} \mathrm{C}$ with $\mathrm{Spd}$ foliar spraying; $\mathrm{T} 2=$ plants under $42 / 32{ }^{\circ} \mathrm{C}$; and $\mathrm{T} 2+=$ plants under $42 / 32{ }^{\circ} \mathrm{C}$ with Spd foliar spraying. Arrows indicate the CAT isozymes detected by staining.

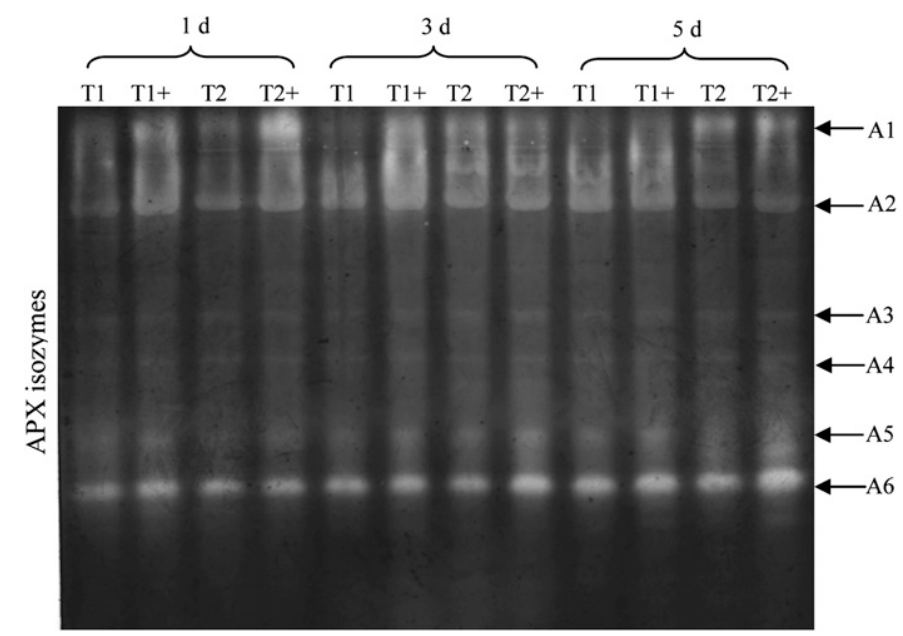

Fig. 7. Effect of high-temperature stress and/or exogenous application of $1 \mathrm{~mm}$ spermidine (Spd) on the ascorbate peroxidase (APX) isozymes in leaves of cucumber seedlings during treatments for 1,3 , and $5 \mathrm{~d}$. APX isozymes were detected on $8 \%$ native polyacrylamide gels. $\mathrm{T} 1=$ control plants under $28 / 18{ }^{\circ} \mathrm{C}$ (day/night); $\mathrm{T} 1+=$ plants under $28 / 18^{\circ} \mathrm{C}$ with Spd foliar spraying; $\mathrm{T} 2=$ plants under $42 / 32{ }^{\circ} \mathrm{C}$; and $\mathrm{T} 2+=$ plants under $42 / 32{ }^{\circ} \mathrm{C}$ with Spd foliar spraying. Arrows indicate the APX isozymes detected by staining.

the three types of polyamines, the conversion from Put to Spd and $\mathrm{Spm}$ in leaves of cucumber seedlings under high-temperature stress may be a kind of adaptive response of this cultivar. Exogenous Spd application modulated the changes of endogenous polyamines levels in cucumber seedlings under hightemperature stress; it promoted Spd and its diamine obligate precursor Put to increase and inhibited its downstream product Spm to maintain a higher Spd level. Of the three major polyamines, Spd has the highest content in cucumber seedlings. Studies have shown that Spd was most closely associated with cold (Shen et al., 2000) and salt stress (Duan et al., 2008). Similarly, in the present study, endogenous Spd content was 
most pronounced to respond to high-temperature stress and exogenous Spd application, which suggested that Spd maybe also the most important type of polyamines for cucumber seedlings to obtain heat adaptability.

Diverse environmental stresses differentially affect cellular homeostasis and induce the formation of ROS, which cause oxidative damage to membrane, lipids, proteins, and nucleic acids (Srivalli et al., 2003). Under optimum temperature conditions, plants maintain a balance between producing and scavenging ROS (Bowler et al., 1992) through a well-coordinated and rapidly responsive antioxidant system. Because extreme temperatures cause damage in cellular membranes, heat stress may disturb the balance and promote lipid peroxidation either by increasing the production of ROS or by decreasing the scavenging ability of ROS in the cell (Bowler et al., 1992). However, the extent of ROS production always exceeds the antioxidant defense capability of cell under high-temperature stress (Almeselmani et al., 2006). MDA is a product of peroxidation of unsaturated fatty acids in phospholipids and is responsible for cell membrane damage (Halliwell and Gutteridge, 1989). As an ubiquitous enzyme in plants, LOX catalyzes the dioxygenation of the plant fatty acids, linoleic, and linolenic acids and has deleterious effects on membranes and proteins (Du et al., 2010; Todd et al., 1990). LOX is involved in the activation of membrane lipid peroxidation by catalyzing the oxidation of polyunsaturated fatty acids to ROS (Fobel et al., 1987). LOX hydroperoxide products cause senescence and are involved in inactivation of protein synthesis and deterioration of cellular membranes (Avdiushko et al., 1993). Our results showed that high-temperature stress significantly increased the MDA content and LOX activity in leaves of cucumber seedlings (Fig. 1). Free radicals result from the peroxidation of membrane lipids, which occurs when levels of ROS and/or LOX activity are increased (Croft et al., 1990). Exogenous Spd reversed the severe lipid peroxidation under high-temperature stress. This result is in agreement with a previous report in which increased levels of Spd and Spm prevented membrane destabilization in senescing oat (Avena sativa) leaves (Tiburcio et al., 1994). As a result of their cationic nature at a physiological $\mathrm{pH}$, PAs can interact with macromolecules by hydrogen and ionic bonding and electrostatic and hydrophobic interaction. They also can conjugate to small molecules such as proteins in the plasma membrane, antibiotics, phenolic acids, and hydroxycinnamic acid noncovalently (Feuerstein and Marton, 1989; Martin-Tanguy, 2001). PAs play an important role in stabilizing the function of this biomembrane (Galston and Kaur-Sawhney, 1995). In this study, exogenous Spd effectively alleviated this increase of ROS under hightemperature stress. Plants possess several mechanisms to combat increased ROS levels during abiotic stress conditions; they appear to purposefully generate ROS as signaling molecules to control stomatal behavior and programmed cell death (Apel and Hirt, 2004). The major ROS-scavenging enzymes of plants include SOD, POD, CAT, APX, glutathione peroxidase, and peroxiredoxin. SOD converts $\mathrm{O}_{2}^{-}$. to $\mathrm{H}_{2} \mathrm{O}_{2}$, whereas POD, CAT, and APX help to minimize the damaging effects of $\mathrm{H}_{2} \mathrm{O}_{2}$ by converting it into oxygen and water. The balance between SOD and the different $\mathrm{H}_{2} \mathrm{O}_{2}$-scavenging enzymes is considered to be crucial for determining the steady-state level of ROS (Mittler et al., 2004). In the present study, regardless of whether the activities of these enzymes were inhibited or raised by hightemperature stress, exogenous Spd had promoting effects on them. PAs have been tested as antioxidants under some adverse environmental conditions, although their precise role as antioxidants is still a matter of debate (Groppa et al., 2001). The antioxidative effect of PAs is the result of a combination of their anion- and cation-binding properties involving a radical scavenging function and capability of inhibiting both lipid peroxidation and metal-catalyzed oxidative reactions (Tadolini, 1988). Alternatively, PA catabolism produces $\mathrm{H}_{2} \mathrm{O}_{2}$, a signaling molecule that can enter the stress signal transduction chain to promote the activation of antioxidative defense response but can also act as a prooxidant agent (Groppa et al., 2007).

Gel electrophoresis of proteins has become a standard and powerful research tool in a multitude of biological disciplines, and isozyme analysis has become a particularly prominent technique in systematic and evolutionary biology and agronomy (Vallejos, 1983). Isozymes are enzymes that share a common substrate but differ in electrophoretic mobility. The foremost reason for the popularity of the technique is that isozymes provide a series of readily scored single-gene markers (Wendel and Weeden, 1989). Various antioxidant isozymes are differentially compartmentalized and, depending on the tissue, are likely to respond differently to cold acclimation in maize (Zea mays) seedlings; elevated CAT-3 is the first line of defense from mitochondria-generated $\mathrm{H}_{2} \mathrm{O}_{2}$; nine of the most prominent POD isozymes were induced by acclimation (Anderson et al., 1995). Clearly, it is necessary to study the status of the various antioxidant isozymes under high-temperature stress so as to assess their contribution to heat tolerance.

The distinction of three types of SOD enzymes is based on the metal ion in their active sites: copper and zinc, manganese, or iron. To maintain balance between the rates of $\mathrm{O}_{2}^{-}$. generation and removal, plants have evolved elaborate regulatory mechanisms to control the synthesis of SODs in response to oxidative stress (Scandalios, 1993). In the present study, the predominant SOD isozyme was inhibited by high-temperature stress but induced by exogenous Spd. It is conceivable that Spd may result in a high SOD protein turnover and promote more or new SOD enzyme synthesis to maintain sufficient SOD levels. Through the effective work of SOD isozymes, the toxicity of ROS is relegated from $\mathrm{O}_{2}^{-} \cdot$ to $\mathrm{H}_{2} \mathrm{O}_{2}$, then the $\mathrm{H}_{2} \mathrm{O}_{2}$ scavenging enzymes come into play. In most higher plants, the POD isozymes, a large family of monomeric heme-containing enzymes of 32 to $45 \mathrm{kDa}$, are divided into three subgroups based on their pI: anionic, neutral, or cationic; and the anionic POD isozymes are most extensively studied in response to developmental and environmental factors (Huh et al., 1997). The increase in POD activity indicated an accelerated ROS production and a high MDA content indicated membrane lipid peroxidation in creeping bentgrass (Agrostis palustris) under heat stress (Liu and Huang, 2000). In the present study, POD activity was greatly increased in leaves of cucumber seedlings just $1 \mathrm{~d}$ after starting treatment, and POD isozyme abundance was enhanced after $5 \mathrm{~d}$ of treatment, indicating that the cultivar used in the experiment possesses a strong POD system to deal with high-temperature stress. However, with the time of treatment, exogenous Spd was required to maintain higher POD activity and isozyme expression levels. Huh et al. (1997) have suggested that POD plays a significant role in plant responses to stress. Our results support this view; perhaps POD is the key functional antioxidant enzyme in cucumber under heat stress. In maize, CAT-1, CAT-2, and CAT-3 are three biochemically distinct CAT isozymes; the levels of total scutellar CAT normally detected at $25^{\circ} \mathrm{C}$ were significantly reduced at 35 and 
$40^{\circ} \mathrm{C}$ (Roupakias et al., 1980). Both temporal and spatial changes in the pattern of CAT isozyme expression occurred during the course of normal postgerminative development (Scandalios et al., 2000). The reported patterns of CAT-1 and CAT-2 in maize are very similar with that obtained in the present study in cucumber. Interestingly, we found that CAT activity and isozyme expression levels were greatly enhanced by exogenous Spd, whether under optimum or high temperature. However, such a feature of Spd still needs to be tested on other species. APX is one of the most important antioxidant enzymes in plants for the detoxification of $\mathrm{H}_{2} \mathrm{O}_{2}$, and the different isoforms are active in chloroplasts, cytosol, and microsomes. In A. thaliana, the Apx1 and Apx2 genes encoding cytosolic APX were heat stressed and HSF dependently expressed; Apx2 is a novel heat shock gene and the enzymatic activity of $\mathrm{APX} 2 / \mathrm{APX}^{\mathrm{S}}$ is required to compensate for the heat stress-dependent decline of APX1 activity (Panchuk et al., 2002). In embryogenic callus of litchi (Litchi chinensis), APX activity was higher at 30 and $35^{\circ} \mathrm{C}$ than at $25^{\circ} \mathrm{C}$, whereas it was lower at $40^{\circ} \mathrm{C}$; in addition, the intensity of APX isozyme bands was also elevated at 30 and $35^{\circ} \mathrm{C}$, and the intensity and number of bands decreased at $40^{\circ} \mathrm{C}$ (Shao et al., 2010). In our study, APX activity was greatly decreased under $42 / 32{ }^{\circ} \mathrm{C}$ (day/night), and exogenous Spd effectively alleviated the decline of APX activity, but the role of Spd in the enhancement of APX isozymes was relatively weak.

In this study, high-temperature stress caused a clear suppression of growth in cucumber seedlings; an enhanced level of lipid peroxidation and a higher level of ROS were observed in leaves suggesting that oxidative stress had occurred. These harmful physiological effects were alleviated by exogenous application of Spd and eventually the growth inhibition could also be reversed by exogenous Spd. In conclusion, foliar spraying of Spd increased the heat tolerance of cucumber seedlings by adjusting the ratio of three different PAs and inducing a stronger antioxidant system to alleviate the oxidative stress induced by high-temperature stress.

\section{Literature Cited}

Aebi, H. 1984. Catalase in vitro. Methods Enzymol. 105:121-126.

Almeselmani, M., P. Deshmukh, R. Sairam, S. Kushwaha, and T. Singh. 2006. Protective role of antioxidant enzymes under high temperature stress. Plant Sci. 171:382-388.

Anderson, M., T. Prasad, and C. Stewart. 1995. Changes in isozyme profiles of catalase, peroxidase, and glutathione reductase during acclimation to chilling in mesocotyls of maize seedlings. Plant Physiol. 109:1247-1257.

Apel, K. and H. Hirt. 2004. Reactive oxygen species: Metabolism, oxidative stress, and signal transduction. Annu. Rev. Plant Biol. 55:373-399.

Avdiushko, S., X. Ye, D. Hildebrand, and J. Kuc. 1993. Induction of lipoxygenase activity in immunized cucumber plants. Physiol. Mol. Plant Pathol. 42:83-95.

Axelrod, B., T.M. Cheesbrough, and S. Laakso. 1981. Lipoxygenase from soybeans. Methods Enzymol. 71:441-451.

Baniwal, S., K. Bharti, K. Chan, M. Fauth, A. Ganguli, S. Kotak, S. Mishra, L. Nover, M. Port, and K. Scharf. 2004. Heat stress response in plants: A complex game with chaperones and more than twenty heat stress transcription factors. J. Biosci. 29:471-487.

Beauchamp, C. and I. Fridovich. 1971. Superoxide dismutase: Improved assays and an assay applicable to acrylamide gels. Anal. Biochem. 44:276-287.

Bouchereau, A., A. Aziz, F. Larher, and J. Martin-Tanguy. 1999. Polyamines and environmental challenges: Recent development. Plant Sci. 140:103-125.
Bowler, C., M. Van Montagu, and D. Inzé. 1992. Superoxide dismutase and stress tolerance. Annu. Rev. Plant Physiol. Plant Mol. Biol. 43:83-116.

Bradford, M.M. 1976. A rapid and sensitive method for the quantitation of microgram quantities of protein utilizing the principle of protein-dye binding. Anal. Biochem. 72:248-254.

Cheng, L., Y. Zou, S. Ding, J. Zhang, X. Yu, J. Cao, and G. Lu. 2009. Polyamine accumulation in transgenic tomato enhances the tolerance to high temperature stress. J. Integr. Plant Biol. 51:489-499.

Croft, K., C. Voisey, and A. Slusarenko. 1990. Mechanism of hypersensitive cell collapse: Correlation of increased lipoxygenase activity with membrane damage in leaves of Phaseolus vulgaris (L) inoculated with an avirulent race of Pseudomonas syringae pv. phaseolicola. Physiol. Mol. Plant Pathol. 36:49-62.

Du, C., H. Fan, S. Guo, and T. Tezuka. 2010. Applying spermidine for differential responses of antioxidant enzymes in cucumber subjected to short-term salinity. J. Amer. Soc. Hort. Sci. 135:18-24.

Duan, J., J. Li, S. Guo, and Y. Kang. 2008. Exogenous spermidine affects polyamine metabolism in salinity-stressed Cucumis sativus roots and enhances short-term salinity tolerance. J. Plant Physiol. 165:1620-1635.

Elstner, E. and A. Heupel. 1976. Inhibition of nitrate formation from hydroxylammonium chloride: A simple assay for superoxide dismutase. Anal. Biochem. 70:616-620.

Feuerstein, B. and L. Marton. 1989. Specificity and binding in polyamine/nucleic acid interactions, p. 109-124. In: Bachrach, U. and Y.M. Heimer (eds.). The physiology of polyamines. 1. CRC Press, Boca Raton, FL.

Fobel, M., D. Lynch, and J. Thompson. 1987. Membrane deterioration in senescing carnation flowers: Coordinated effects of phospholipid degradation and the action of membranous lipoxygenase. Plant Physiol. 85:204-211.

Galston, A. and R. Kaur-Sawhney. 1995. Polyamines as endogenous growth regulators, p. 158-178. In: Davies, P.J. (ed.). Plant hormones: Physiology, biochemistry, and molecular biology. 2nd Ed. Kluwer Academic Publishers, Norwell, MA.

Giannopolitis, C. and S. Ries. 1977. Superoxide dismutases: II. Purification and quantitative relationship with water-soluble protein in seedlings. Plant Physiol. 59:315-318.

Groppa, M. and M. Benavides. 2008. Polyamines and abiotic stress: Recent advances. Amino Acids 34:35-45.

Groppa, M., M. Ianuzzo, M. Tomaro, and M. Benavides. 2007. Polyamine metabolism in sunflower plants under long-term cadmium or copper stress. Amino Acids 32:265-275.

Groppa, M., M. Tomaro, and M. Benavides. 2001. Polyamines as protectors against cadmium or copper-induced oxidative damage in sunflower leaf discs. Plant Sci. 161:481-488.

Halliwell, B. and J. Gutteridge. 1989. Free radicals in biology and medicine. 2nd Ed. Clarendon Press/Oxford University Press, New York, NY.

Heath, R. and L. Packer. 1968. Photoperoxidation in isolated chloroplasts: I. Kinetic and stoichiometry of fatty acid peroxidation. Arch. Biochem. Biophys. 125:189-198.

Huh, G., S. Lee, Y. Bae, J. Liu, and S. Kwak. 1997. Molecular cloning and characterization of cDNAs for anionic and neutral peroxidases from suspension cultured-cells of sweet potato and their differential expression in response to stress. Mol. Gen. Genet. 255:382-391.

Hunt, R. 1990. Basic growth analysis: Plant growth analysis for beginners. Unwin Hyman, London, UK.

Kasukabe, Y., L. He, K. Nada, S. Misawa, I. Ihara, and S. Tachibana. 2004. Overexpression of spermidine synthase enhances tolerance to multiple environmental stresses and up-regulates the expression of various stress-regulated genes in transgenic Arabidopsis thaliana. Plant Cell Physiol. 45:712-722.

Kochba, J., S. Lavee, and P. Spiegel-Roy. 1977. Differences in peroxidase activity and isoenzymes in embryogenic and non-embryogenic 'Shamouti' orange ovular callus lines. Plant Cell Physiol. 18:463-467. 
Liu, X. and B. Huang. 2000. Heat stress injury in relation to membrane lipid peroxidation in creeping bentgrass. Crop Sci. 40:503-510.

Martin-Tanguy, J. 2001. Metabolism and function of polyamines in plants: Recent development (new approaches). Plant Growth Regulat. 34:135-148.

Mittler, R. 2002. Oxidative stress, antioxidants and stress tolerance. Trends Plant Sci. 7:405-410.

Mittler, R., S. Vanderauwera, M. Gollery, and F. Van Breusegem. 2004. Reactive oxygen gene network of plants. Trends Plant Sci. 9:490-498.

Mittler, R. and B. Zilinskas. 1993. Detection of ascorbate peroxidase activity in native gels by inhibition of the ascorbate-dependent reduction of nitroblue tetrazolium. Anal. Biochem. 212:540-546.

Nakano, Y. and K. Asada. 1987. Purification of ascorbate peroxidase in spinach chloroplasts; its inactivation in ascorbate-depleted medium and reactivation by monodehydroascorbate radical. Plant Cell Physiol. 28:131-140.

Panchuk, I., R. Volkov, and F. Schöffl. 2002. Heat stress- and heat shock transcription factor-dependent expression and activity of ascorbate peroxidase in Arabidopsis. Plant Physiol. 129:838-853.

Patterson, B., E. MacRae, and I. Ferguson. 1984. Estimation of hydrogen peroxide in plant extracts using titanium (IV). Anal. Biochem. 139:487-492.

Roupakias, D., D. McMillin, and J. Scandalios. 1980. Chromosomal location of the catalase structural genes in Zea mays using BA translocations. Theor. Appl. Genet. 58:211-218.

Scandalios, J. 1993. Oxygen stress and superoxide dismutases. Plant Physiol. 101:7-12.

Scandalios, J., A. Acevedo, and S. Ruzsa. 2000. Catalase gene expression in response to chronic high temperature stress in maize. Plant Sci. 156:103-110.

Shao, W., Z. Lai, Q. Huang, and Y. Guo. 2010. Changes of APX isozymes under high-temperature stress and cloning of an APX functional fragment in embryogenic callus of litchi. Acta Hort. 863:183-188.

Sharma, P. and M. Rajam. 1995. Spatial and temporal changes in endogenous polyamine levels associated with somatic embryogenesis from different hypocotyl of eggplant (Solanum melongena L.). J. Plant Physiol. 146:658-664.

Shen, W., K. Nada, and S. Tachibana. 2000. Involvement of polyamines in the chilling tolerance of cucumber cultivars. Plant Physiol. 124:431-439.

Song, L., W. Ding, M. Zhao, B. Sun, and L. Zhang. 2006. Nitric oxide protects against oxidative stress under heat stress in the calluses from two ecotypes of reed. Plant Sci. 171:449-458.

Srivalli, B., V. Chinnusamy, and R. Khanna-Chopra. 2003. Antioxidant defense in response to abiotic stresses in plants. J. Plant Biol. 30:121-139.

Tadolini, B. 1988. Polyamine inhibition of lipoperoxidation. The influence of polyamines on iron oxidation in the presence of compounds mimicking phospholipid polar heads. Biochem. J. 249:33-36.

Tiburcio, A., R. Besford, T. Capell, A. Borrell, P. Testillano, and M. Risueno. 1994. Mechanisms of polyamine action during senescence responses induced by osmotic stress. J. Expt. Bot. 45:1789-1800.

Todd, J., G. Paliyath, and J. Thompson. 1990. Characteristics of a membrane-associated lipoxygenase in tomato fruit. Plant Physiol. 94:1225-1232.

Vallejos, C. 1983. Enzyme activity staining, p. 495-516. In: Tanksley, S. and T. Orton (eds.). Isozymes in plant genetics and breeding. Part A. Elsevier, Amsterdam, The Netherlands.

Wahid, A., S. Gelani, M. Ashraf, and M. Foolad. 2007. Heat tolerance in plants: An overview. Environ. Exp. Bot. 61:199-223.

Wendel, J. and N. Weeden. 1989. Visualization and interpretation of plant isozymes, p. 5-45. In: Soltis, D. and P. Soltis (eds.). Isozymes in plant biology. Adv. Plant Sci. Ser. 4. Dioscorides Press, Portland, OR.

Woodbury, W., A. Spencer, and M. Stahmann. 1971. An improved procedure using ferricyanide for detecting catalase isozymes. Anal. Biochem. 44:301-305.

Zhao, F., C. Sun, Y. Liu, and Z. Liu. 2000. Effects of salinity stress on the levels of covalently and noncovalently conjugated polyamines in plasma membrane and tonoplast isolated from barley seedlings. Acta Bot. Sin. 42:920-926. 